\title{
Czech and Polish Higher Education - from Bureaucracy to Market Competition*
}

\author{
NATALIE SIMONOVÁ, DOMINIK ANTONOWICZ** \\ Institute of Sociology AS CR, Prague, Nicolaus Copernicus University, Toruń
}

\begin{abstract}
This article aims to compare two aspects of the education systems in two East European countries. As the political history of the Czech Republic and Poland in the past fifty years is similar, the authors compare the countries' development in tackling educational inequalities and attempt to evaluate their policies and reforms from the beginning of socialism to date. Despite many similarities and identical outcomes in the past (no effect in lowering levels of educational inequalities), these countries undertook two different approaches to the transformation of higher education after 1989. The specific current developments in higher education in the Czech Republic and Poland have been caused by conservative and reserved legislation in the former and the creation of new, very liberal rules for establishing non-state higher education institutions in the latter. As there emerged a considerable difference in the number of higher education institutions in each country, the authors show the negative impact on educational inequalities and the social consequences of the enormous increase in the number of students and private universities. Despite different approaches, the countries face many similar problems, such as quality assurance, a shortage of staff, and information asymmetry. These problems seem to be sharper in Poland, but it is only a matter of time for the Czech Republic.
\end{abstract}

Keywords: education system, educational inequality, higher education, market competition

Sociologický časopis/Czech Sociological Review, 2006, Vol. 42, No. 3: 517-536

* The core institutional support for this article was provided by the Ministry of Labour and Social Affairs of the Czech Republic (Grant 1J005/04-DP2: Inequality of Educational Opportunities: The Extent, Causes, Social and Economic Effects, Solution Strategies) and by the Grant Agency of the Czech Republic (Grant 403/06/1241: Educational Mobility and Educational Inequalities in the Czech Republic between 1936 and 2004).

** Direct all correspondence to: Natalie Simonová, Institute of Sociology AS CR, Jilská 1, 110 00, Prague 1, Czech Republic, e-mail: natalie.simonova@soc.cas.cz; Dominik Antonowicz, Instytut Socjologii, Uniwersyet Mikołaja Kopernika, ul. Fosa Staromiejska 1a, 87-100 Torun, Poland, e-mail: dominik.antonowicz@uni.torun.pl

(C) Sociologický ústav AV ČR, Praha 2006 


\section{The bureaucratic nature of the education systems in the Czech Republic and Poland}

After the onset of socialism in Central Europe in 1948, the Czech and Polish education systems underwent changes that with some simplification can be referred to as a process of 'sovietisation'. By approximating the Soviet model of education system (e.g. the introduction of unitary compulsory primary education, the abolition of tuition fees and private schools altogether, social origin becoming subject to scrutiny), the Czech Republic, Poland and other socialist countries strove to attain 'equal access to education'. This was to ensure that all social classes were represented in secondary and especially higher education to a degree that reflected the proportion of each class in the population. Governments believed this would ensure the 'accessibility of all educational forms to all citizens regardless of their social standing' [Historická statistická... 1985: 39]. It must be said at the outset that this intention failed.

Poland and the Czech Republic had very similar educational policies and experienced similar institutional reforms after the Second World War. Consequently, they saw almost identical developments in the structure of the education system and in educational inequalities, and to date the problems they have been facing remain very similar. Socialist education systems were shaped by the structure of the socialist economy (high priority given to heavy industry, resulting in an emphasis on technical and vocational education) and by the nature of its political ideology (central planning as opposed to free market competition, and the use of quotas in relation to student numbers and subject enrolment). A new intelligentsia was to be drawn from the working class and the peasantry by enabling them access to secondary and higher education, as one of the foci of educational policy was the transformation of the social structure. Educational inequalities as such were regulated by means of egalitarian social policy and resource redistribution. More specifically, education at all levels was provided for free (including textbooks and school aids), 'social scholarships' were granted to the politically privileged for admission to higher education, and social origin, place of residence ('territorial advantage') and nationality (Czech vs. Slovak) were subject to political scrutiny in the admission procedure.

However, as the above-mentioned mechanisms of positive discrimination were not rigorously adhered to, their actual impact on how well represented 'desirable' groups were in the student population was questionable. Higher education in particular resisted such intervention. Traditional full-time study programmes (as opposed to evening and distance-learning programmes) especially defied efforts to establish the proportional representation of social classes. Out of the total number of people that graduated from higher education in Poland between 1945 and 1973, 34\% were from working class families, $23 \%$ from peasant families, $40 \%$ from families of the intelligentsia, and $3 \%$ from the former middle or upper classes. However, secondary and post-secondary school graduates represented just $20 \%$ of the working population in 1972, of which $10 \%$ were the children of peasants and less than $10 \%$ were the children of workers [Adamski and Bialecki 1981]. 
In both the Czech Republic and Poland general post-war developments and the unification of the education system resulted in an objective increase in the average amount of time spent in the education process and in the democratisation and expansion of secondary education, the introduction of evening and distance-learning programmes for economically active members of the population (at both the secondary and post-secondary levels) and the emancipation and even positive discrimination of women. However, the education systems in both countries preserved the intergenerational reproduction of education, and were unable to thwart the traditional process of transmitting educational aspirations and cultural capital. These political aspirations failed to materialise, especially in higher education. The political tools of communist ideology sanctioned the strong dependence of a child's educational career on the decisions made by a child's parents: manual occupations and the levelling of income were glorified in general. Owing to limited income differentiation, the significance of education in the status attainment process decreased or was entirely eliminated. The working class with inconsistent social status (relatively rich) was not interested in education, as financially it simply did not pay off. The system of positive discrimination (assigning points according to social origin, etc.) proved ineffective unless accompanied by individual aspirations. Bureaucratic measures aimed at scrutinising students' social origin were the easiest tool for regulating admissions, but they were short-sighted in their approach to the complex nature of social reproduction.

Self-selection for a certain type of school was more significant than selection based on 'objective' school reports and admission procedures. Not even the often greater weight given to points accorded for social origin and to students coming directly from employment over points based on school results induced any significant change [e.g. Adamski and Bialecki 1981]. The established distribution by social origin based on secondary school type self-selection (by parents or children) was less pronounced later in the transition between secondary and higher education institutions. As the Czech experience shows, the lower social strata's self-selection was also fuelled by the limited income differentiation. There was no compensation for the 'cost' of education except its cultural value and potentially higher social prestige (though prestige scales were socialism-specific, with manual occupations held in higher esteem than intellectual ones).

Another factor in this kind of self-selection was that higher education institutions in the Czech Republic and Poland primarily admitted students from secondary grammar schools. Parents with lower or low education feared the consequences of a potentially unsuccessful transition, and an abstract general education ('this sort of education will provide our child with no skills') represented a somewhat insecure investment that they tended to shy away from [Adamski and Bialecki 1981; Goldthorpe 1996]. Conversely, among the higher social strata, the threat of social descent signified a bigger risk than this kind of insecurity. Adamski and Bialecki also point out the limited awareness among vocational school students of possible occupational choices, their limited ability to assess their own potential, their inade- 
quately formulated interests, and their highly stereotyped occupational choices. In the lower social strata, educational choices are guided by occupational choices. These are in turn negatively affected by poor awareness of the range of occupations that exist, which results in lower educational attainment.

\section{The development of educational inequalities - international comparisons}

In keeping with official egalitarian ideology, socialist governments claimed that there would be a decrease in inequalities in access to education in socialist countries, not only compared to the past but also compared to other, non-socialist countries. Available empirical evidence of educational inequalities in Czechoslovakia and Poland indicates that no actual long-term decrease occurred. In a long-term perspective, inequalities in socialist countries were no lower than in the West. EastWest empirical comparisons demonstrated over time not only that the level of educational inequalities was the same in Poland and the United States [Meyer, Tuma and Zagórski 1979] and in Czechoslovakia, Hungary and the Netherlands [Matéju 1990], but also that inequalities in Poland were lower than in Austria [Haller and Mach 1984], lower than in Finland and Norway [Pohoski, Pontinen and Zagórski 1978], and lower than in the United States when using the Treiman classification [Meyer, Tuma and Zagórski 1979]. However, other studies showed higher inequalities in socialist countries, for example in Czechoslovakia and Hungary compared to the Netherlands [Boguszak, Matějů and Peschar 1990], in Poland compared to Norway and Finland, when social origin was represented by the father's education [Pohoski, Pontinen and Zagórski 1978], and in Poland compared to the Netherlands, when social origin was determined by the father's occupation [Mach and Peschar 1990]. Research on educational mobility exchange has not show any differences between, for example, Poland and the Netherlands (except among younger cohorts), although higher fluidity was reported in Poland [Peschar, Popping and Mach 1986].

It remains a question, however, whether these inequalities formed in the same manner in both types of socio-political system, despite the more or less identical levels of inequality. So far the search for the sources of inequalities has shown that there are differences between socialist and capitalist countries, at least in the diminished impact of potential and aspirations in Eastern countries and the increased role of social capital in education allocation. Education did remain a value and a prerequisite of prestige and success attainment, but its significance weakened and, in an environment where 'non-manual work is no work' was the catchword, it acquired the nature of a useless and unprofitable hobby (at least for certain strata). However, the degree of coincidence between the process of education and social status attainment and the principles of meritocracy, then and now, is not directly quantifiable, and to pursue such a discussion would verge on speculation.

Another as yet unresolved issue is whether and how educational inequalities developed under socialism, that is, whether the official proclamation that thanks to 
state socialism these inequalities decreased can be confirmed. It has been proven [e.g. Haller and Mach 1984] that after the Second World War and the establishment of socialism inequalities decreased, education levels grew significantly, and occupations became increasingly dependent on education, and the overall significance of education, equality and meritocracy grew. The access of lower strata to education improved, especially in the early post-war years (at the onset of socialism). But inequalities increased again in the 1970s in Poland and Czechoslovakia [Haller and Mach 1984; Matějů 1993; Wong 1998; Hanley 2001; Simonová 2003], which made it clear that state socialism was incapable of regulating status allocation and inequality in the long term. There is no unequivocal conclusion about the actual impact of the socialist system on social origin and a child's educational dependence, and individual studies have shown just partial and temporary changes. Nevertheless, in a long-term perspective the effects appear to have been just short-term, temporary oscillations, dependent on the current social policy and overall political developments; they had no permanent impact and did not represent any steady development towards greater equality and justice, resulting in inequality levels lower than in Western countries.

Nevertheless, some studies have shown [e.g. Mach and Peschar 1990] that the connection between a father's occupation and a son's education was closer in the pre-socialist cohorts than in the socialist ones, suggesting that this system did have a positive impact on the development of educational inequalities. The debate remains, however, whether the initially reduced impact of social origin can be ascribed to the rapid expansion of the school system as a direct consequence of general post-war industrialisation [Boguszak, Matějů and Peschar 1990; Nieuwbeerta and Rijken 1996; Hanley 2001], or, for instance, to the quota interventions in admissions to secondary [Kreidl 2001] and post-secondary schools. However, the secondary to higher level transition did not display any significant changes, and instead the trade-off between the moderate decrease or stability in inequalities and the significant increase of downward as opposed to upward mobility in men was observed [Matějů 1986]. The hypothesis about the positive impact of socialist educational policy seems most forcefully opposed by the argument that the general increase in educational levels and dynamic industrialisation represented the strongest influence in Eastern and Western countries. That is why similar patterns of socioeconomic reproduction have been found in some comparisons, for example, between Poland and the Netherlands [Mach and Peschar 1990].

\section{The impact of socialist educational policy on the development of higher education after 1989}

Leaving aside issues of methodological inconsistencies, varied classifications (specifically with regard to the father's occupation), and diverse data sets, several general conclusions can be drawn regarding the developments in the approach to higher education in the Czech Republic and Poland in the past fifty years. All em- 
pirical evidence shows that, although it was not the explicit intent of the socialist governments, socialism definitely brought about greater gender equality in the transition to higher education. After an initial decrease in the 1950s and 1960s, socioeconomic inequality either remained unchanged or began to grow again (in the 1970s and 1980s), its overall level was thus more or less stable. Moreover, as the number of people with complete secondary education, that is, the number of potential post-secondary students, increased, and the proportion of those admitted to study remained unchanged (for example, the proportion of higher-education achievers in Poland from the end of the Second World War until 1987 was 9-12\% of each cohort), the probability of admission to higher education decreased. While each cohort did have more opportunities to study (the influence of social origin on the attained level of education decreased over time), the manner in which opportunities were allocated remained unaltered [e.g. Nieuwbeerta and Rijken 1996].

During the socialist period, the parents' education was more important than the father's class position for making a successful transition from secondary to higher education [Heyns and Bialecki 1993; Matějů 1993]. According to Matějü, Reháková and Simonová [2003], after 1989, the impact of the parents' education remained unaffected, while the impact of the father's class increased dramatically. The authors claim that this development was primarily the result of the significant decrease in relative chances among children of unqualified and semi-qualified workers, compared to the children from other social classes, and in their view, inequalities caused by the impact of social origin only began to grow after 1989 . However, the use of different data and different methodologies have indicated that the father's education remained crucial after 1989, while the father's class has shown no inter-cohort changes, and overall inequalities in access to higher education have been stable or decrease since 1989 in comparison with the 1970s and 1980s [Simonová 2003].

Secondary school selection has become the crucial point in the educational careers of Czech and Polish students. In both countries, past and present, it has been what determines whether or not an individual can continue to study to a significantly higher level. Although the number of people with the secondary school-leaving exam increased through the years, a quarter of all women and almost half of all men born between 1960 and 1969 in Poland finished school with lower vocational education, that is, without the secondary school-leaving exam, a prerequisite for applying to higher education institutions [Heyns and Bialecki 1993]. Sadly, for the Czech Republic the figures were even higher. Fortunately, when the centrally planned economy was abandoned, educational aspirations and secondary and postsecondary educational opportunities grew significantly. The current higher demand for higher education is the consequence of the growing economic payoff of education and a social ideology that stresses education as an important means of preventing social exclusion.

Since the beginning of the 1990s, analysts at the OECD have been pointing out the inevitability of a transformation in higher education, noting the shift away from 
elite to mass higher education, and the need for the diversification of higher education (the introduction of non-university higher education, bachelor degree programmes, etc.) [Čerych 2002]. The Czech and Polish governments have taken different approaches to this problem, as will be noted below. The problem of higher education funding had begun to emerge. Some authors (and politicians) consider multi-source financing the best way to expand the education system further, along with the development of a competitive economy. Some authors [Tomusk 2000] view the introduction of tuition fees for lucrative study fields (business, law) as a new mechanism of reproducing state nobility.

\section{Two routes to excellence}

Despite their similar pasts, the Czech Republic and Poland undertook two different approaches to the transformation of higher education after 1989. In the Czech Republic, the Higher Education Act of 1990 created room for the democratic control of universities. The act was intended as a demonstration of good will on the part of the new state authorities, but the new act's (No. 172/1990) ratification by the Assembly of the Czech and Slovak Federal Republic was also meant to introduce the principles of a market economy into education. 'It put substantial decision-making power back into hands of the university and its faculty and students. The law emphasized academic rights and freedom as important principles of democracy, and envisioned democracy in terms of self government and autonomous decision-making within higher education communication' [McMullen and Prucha 2000: 63].

This entailed a return to a system of autonomous academic institutions based on principles of self-government. Academic freedom was meant to promote independent knowledge and creativity. Despite being a great historical achievement in a political perspective, the Act failed to create a legislative framework for establishing private universities or colleges. There were no legislative obstacles to setting up private institutions of higher education, but the Act did not establish a legal procedure for applying for 'state accreditation' to legitimise the instruction offered and to guarantee recognition by the state of degrees awarded. This seriously undermined the development of private sector institutions, because for them accreditation plays a vital role in reassuring students about the quality of the knowledge and skills the institution is offering them.

This somewhat conservative and reserved legislation made the situation of higher education in the Czech Republic very different from that in Poland. In September 1990, just twelve months after the communist state was abolished, the Polish Parliament also passed a Higher Education Act, which paved the way to the emergence of free, liberal and autonomous higher education in Poland. It granted greater autonomy to universities by restoring decision-making power to the rectors and the academic senates and giving them back the authority to manage and govern the university. Luckily, despite the communist past, cultural barriers had al- 
Table 1. Institutional development of the education system in Poland and the Czech Republic between 1996 and 2002

\begin{tabular}{lrrrrrrr}
\hline Year & 1996 & 1997 & 1998 & 1999 & 2000 & 2001 & 2002 \\
\hline Applications for state approval (cz) & & & & 13 & 20 & 19 & 19 \\
HEIs with state approval (cz) & & & & 5 & 9 & 11 & 2 \\
Applications under consideration (cz) & & & & 8 & 11 & 8 & 14 \\
Polish private HEIs (pl) & 115 & 148 & 158 & 181 & 206 & 239 & 258 \\
\hline
\end{tabular}

Source: Beneš, Huisman and Šebková [2003: 51].

lowed the academic community to remain strong, and liberal universities had an important impact on the direction the changes contained in the Act of 1990 ultimately took [Jabłecka 1994: 14].

A crucial feature of the Polish act not enacted in the Czech Republic was the creation of new and very liberal rules for establishing non-state higher education institutions. The new legal framework soon appeared to be a driving force for dynamic growth and differentiation of higher education institutions. The 'marketisation' of Polish higher education was of course nothing new, as similar institutional changes in higher education were seen elsewhere in Europe, and in New Zealand and Australia at the beginning of 1990s. However, among East-European Countries it was a radical move toward a market approach, and the two major forms of this approach distinguished by Gareth Williams, privatisation and the creation of quasi-markets [1997: 277], were adopted in the region. Given that Poland and the Czech Republic employed two considerably different approaches to establish new systems of higher education, there also emerged considerable differences in the number of higher education institutions (HEIs), as illustrated in Table 1.

Table 1 compares the institutional development in Poland and the Czech Republic, illustrating the two different paths of development. In the case of the Czech Republic, it also reveals the strong need for alternative means of providing higher education. Despite the 'unfriendly' legislation, there is a growing number of institutions offering their services on the market without state accreditation. Moreover, it is very likely that private universities and colleges that are already well rooted do not need any 'state accreditation', as they have managed to attain and enjoy a good reputation independently and have already earned enough credit to operate successfully on the market.

By contrast, it is striking that in Poland private sector institutions are the driving force of the entire education system. According to Bronisław Misztal [2000] these changes may be a 'beacon' of the Polish transformation. Such a phenomenon, illustrated in Table 2, is in its scale and scope unique for the post-communist countries. 
Table 2. Numbers of higher education institutions in Poland and the Czech Republic

\begin{tabular}{lcccc}
\hline Academic Years & $\begin{array}{c}\text { Numbers of HEI (state + non-state) } \\
\text { Poland }\end{array}$ & $\begin{array}{c}\text { Number of non-state HEI } \\
\text { Czech Republic }\end{array}$ & Poland & Czech Republic \\
\hline $1991 / 1992$ & 117 & 24 & 10 & 0 \\
$1992 / 1993$ & 124 & 23 & 18 & 0 \\
$1994 / 1995$ & 161 & 23 & 56 & 0 \\
$1995 / 1996$ & 179 & 23 & 80 & 0 \\
$1996 / 1997$ & 213 & 23 & 115 & 0 \\
$1997 / 1998$ & 246 & 23 & 146 & 0 \\
$1998 / 1999$ & 266 & 23 & 158 & 0 \\
$1999 / 2000$ & 287 & 23 & 174 & 0 \\
$2000 / 2001$ & 310 & 31 & 195 & 8 \\
$2001 / 2002$ & 344 & 41 & 377 & 17 \\
$2002 / 2003$ & 377 & 57 & 252 & 33 \\
\hline
\end{tabular}

Source: Higher Education Institutions and Their Finances in 1999; GUS (The National Statistics Office) [2001]; Wasielewski [2001], ÚIV (Institute for Information in Education).

What is even more fascinating is that the private sector of higher education does not fit in with the overall picture of privatisation in Poland. It neither emerged out of destroyed (bankrupted) state institutions nor from the transfer of ownership from public to 'foreign hands', which was the most frequent occurrence in other areas [Misztal 2000]. On the contrary, from the very beginning, private universities and colleges grew freely, despite the existence of well-established public universities. This has been possible because the private institutions seem to differ considerably from public ones in terms of the students they target. They play a role that is complementary to the state universities, broadening the participation in higher education, but not forcing any public universities out of business.

Private institutions are generally much smaller in size than the public ones, which gives them greater flexibility to adjust their course selection to meet their clients' needs. Although there is no single model for private universities, three predominant types of private institutions can be distinguished:

1. Higher education institutions established in small cities or cities without academic traditions. Apart from a few exceptions, they do not enjoy an outstanding reputation, but they are more focused on vocational training. These schools usually target local students who cannot afford - economically, socially or culturally - full-time study at public universities. These institutions can also be found in the Czech Republic.

2. Higher education institutions established in big academic cities. They also play a slightly different role than public universities, having a more vocational orien- 
Table 3. Changes in Polish and Czech higher education

\begin{tabular}{|c|c|c|c|c|c|c|c|c|}
\hline \multirow[t]{2}{*}{ Academic years } & \multicolumn{2}{|c|}{ Number of HEIs } & \multicolumn{2}{|c|}{$\begin{array}{l}\text { Number of } \\
\text { students }\end{array}$} & \multicolumn{2}{|c|}{$\begin{array}{l}\text { Number of } \\
\text { academics }\end{array}$} & \multicolumn{2}{|c|}{$\begin{array}{c}\text { Average number } \\
\text { of students per } \\
\text { teacher }\end{array}$} \\
\hline & Poland & CR & Poland & CR & Poland & $\mathrm{CR}$ & Poland & CR \\
\hline 1990/1991 & 112 & 24 & 403800 & 118194 & 64500 & 11839 & 6.3 & 10.0 \\
\hline 1991/1992 & 117 & 23 & 428200 & 113654 & 63200 & 11958 & 6.8 & 9.5 \\
\hline 1992/1993 & 124 & 23 & 495700 & 117637 & 63000 & 12105 & 7.9 & 9.7 \\
\hline 1993/1994 & 140 & 23 & 584000 & 127137 & 65300 & 12561 & 8.9 & 10.1 \\
\hline 1994/1995 & 160 & 23 & 682200 & 136566 & 67100 & 12625 & 10.2 & 10.8 \\
\hline 1995/1996 & 179 & 23 & 794600 & 148433 & 67000 & 12890 & 11.9 & 11.5 \\
\hline 1996/1997 & 213 & 23 & 927500 & 166123 & 70400 & 12969 & 13.2 & 12.8 \\
\hline 1997/1998 & 246 & 23 & 1091800 & 177723 & 74100 & 13216 & 14.7 & 13.4 \\
\hline 1998/1999 & 266 & 23 & 1274000 & 187148 & 77000 & 13292 & 16.5 & 14.1 \\
\hline $1999 / 2000$ & 287 & 23 & 1431900 & 198961 & 77800 & 13592 & 18.4 & 14.6 \\
\hline $2000 / 2001$ & 310 & 31 & 1584800 & 209298 & 79900 & 12791 & 19.8 & 16.4 \\
\hline $2001 / 2002$ & 344 & 41 & 1718700 & 223008 & 86000 & 13641 & 20.0 & 16.3 \\
\hline $2002 / 2003$ & 377 & 57 & 1800500 & 243765 & 88500 & 13846 & 20.3 & 17.6 \\
\hline
\end{tabular}

Source: adapted from Wasielewski [2003] and GUS (The National Statistics Office) [2001], and ÚIV (Institute for Information in Education).

tation and attracting students who do not pass the entrance exams in public fulltime courses.

3. Higher education institutions, which are small, expensive and consequently elite. These institutions often have an outstanding reputation and target highquality students from upper-class families.

The emergence of a private sector had a profound influence on the provision of education in the public sphere. The Higher Education Act (1990) not only created the institutional environment for establishing private universities and colleges, it also helped the public institutions to develop a wide range of alternative forms of teaching, such as part-time and evening courses. Article 70 in the Polish Constitution states, 'education in public schools is free of charge', but in the articles that follow it allows schools to charge for 'certain educational services'. In practice this means that full-time studies at public universities are free, but part-time students and those who take evening courses have to pay tuition fees, and this has given rise to a very profitable business for universities. The exact same situation exists in the Czech Republic. Public universities have consequently turned to engage more in commercial activity, which has helped save them from bankruptcy. The emerging 
private sector, along with the commercial turn in the public one, has led to a dramatic increase in student numbers. But at the same time, owing to a shortage of academic staff, it has had a negative impact on the quality of teaching (see Table 3).

\section{A higher education market - a problem or the solution?}

Numerous scholars have inquired into the the background to the education boom that occurred (in the 1990s) in the post-socialist countries and have sought explanations for the rapid growth in the number of students. One of the most common findings in such research is the increasing value that higher education has for the development of a professional career. Before 1989 the value of higher education was heavily neglected by a system that maintained a dogmatic attachment to and glorification of 'manual work'. In the public opinion, shaped by the state's aggressive propagan$\mathrm{da}$, the universities were generally perceived as places that attract and are comprised of people with no plans or real prospects for professional career development. The collapse of this system in 1989 ushered in revolutionary changes, the socialist myth was gradually debunked and trust restored in the value of academic education. Some leading researchers claim that it is possible to observe positive interdependence between education and income [Danecki 1997; Domanski 1994; Matějů and Kreidl 2001]. In the unstable transitional period at the outset of the transformation (1990-1995), obtaining a higher education degree that would help a person to secure employment and financial stability was extremely important [Rutkowski 1996]. Higher education became an essential component in a person's professional career development, and when obtained by ambitious and hard working individuals it provided certification of a high level of competence and the ability to work. Since 1989 the Poles and Czechs appear to have adopted the belief that the time of meritocracy has arrived and that what really matters now is education. Moreover, higher education has gradually come to be perceived as a wise long-term investment in personal development that is likely to have a positive effect on a person's salary and social position in the near future [Domański 2000; Danecki 1997; Večerník 2001].

\section{Problems with the Polish and the Czech reforms}

The Polish and Czech approaches to the reform of higher education have differed significantly. Polish policy appears to be more market-oriented, while the Czech approach accords the government a stronger position. In both countries policy has on the whole liberated higher education institutions from bureaucratic control, but the pace of the process has been considerably different in each country. Poland experienced much more spontaneous and rapid growth, unlike the Czech Republic, where the process has developed gradually and in a more (government-) controlled manner, and this has led to a number of distinctive features that reflect the differences between them. But they nonetheless have (at least) three major problems in com- 
mon: 1) difficulties measuring the quality of services provided; 2) the information asymmetry in the higher education market, and 3) a shortage of academic staff.

It was the traditional state universities that felt compelled to raise the issue of quality assurance because they are the institutions that would suffer most from a decline in education standards. It has never been clear however what authority should be responsible for assessing the quality of teaching and research. The introduction of market forces in the 1990s led to an increase in the number of tertiary educational institutions (particularly in the private sector) and to a public sector with an increasingly more commercial orientation. Consequently, (particularly in Poland) there has been an enormous concern about a deterioration of the quality of teaching and research. Academics expressed a strong will to sort out the problem by using peer review groups. However, in practice it turned out that they need legal power to enforce educational standards on higher education institutions [see also Sorensen 1993]. In both countries the private sector is quite young and still struggling to exist. Meanwhile, the educational market is becoming more and more competitive, as the demographic 'low tide' is approaching the age of university entrance. It is strongly tempting for private sector institutions to take advantage of the situation and make empty promises in order to attract large numbers of students. In this particular situation the market is failing to secure customers (students) their rights owing to the asymmetry of information (one of the market failures, see Kay and Vickers [1988]). Higher education institutions can take advantage of the students' lack of knowledge about the quality of teaching offered and mislead them. This situation exists in both countries, but in Poland, owing to the larger number of higher education institutions and students, the problem of teaching quality is becoming a major political issue.

The first problem in common is the issue of introducing quality assurance measures. In the Polish context a significant breakthrough was the establishment of the National Commission of Accreditation (Państwowej Komisji Akredytacyjnej $(P K A)$ ), which has been granted legal recognised and endowed with formal powers. The Commission evaluates the performance of higher education institutions and is accountable to the minister of education. It inspects both universities and non-academic institutions and reports its recommendations to the ministry. When it identifies inappropriate practices that may be detrimental to the quality of service provided, the Commission may recommend suspending enrolment for a year or even closing a department or institute. An Accreditation Commission was also set up in the Czech Republic, mainly for the purpose of monitoring the performance of private institutions in terms of how well they fulfil the objectives outlined in their application for a license to found a school. It shares many of the features of the Polish PKA, and both commissions are confronted with the important dilemma of whether to tighten state control and introduce uniform standards for teaching, or whether to increase institutional autonomy and foster the growth of non-traditional institutions, programmes and teaching methods. This dilemma remains a high profile issue and has not yet been solved in Poland or the Czech Republic. 
The second problem concerns the deficit of information about the performance of higher education institutions. As long as there is a stable and limited number of well-established HEIs, students can rely on information about an institution's reputation. But with a rapidly growing number of institutions operating in a competitive environment, a clear need for an independent source of information emerged given the mass of unverified and sometimes completely contradictory information HEIs produce about the quality of their services. There are almost two hundred private HEIs in Poland and the number in the Czech Republic has increased from none in 1999/2000 to 33 (!) in 2002/3. In response to this chaos, league tables began to appear, a well-known practice in Anglo-Saxon countries. League tables are a weighted combination of performance indicator scores, where the total is used to rank institutions such as schools, universities and hospitals [Bowden 2000: 41]. They increasingly started appearing in newspapers and magazines, focusing on different aspects of the performance of HEIs. Of course, the results of the national league tables are compared and discussed (sometimes even questioned and rejected by the academic community) because the selection of performance indicators cannot cover the wide range of academic activity. Despite the growing controversy over the assessment of the performance of university and non-university institutions, it has become increasingly clear that league tables are now an important public relations issue. For many they are a new way of providing and presenting impartial data and more detailed information on universities and their decisions. Despite all the criticism that has been voiced to date about league tables and how they are constructed, and regardless of all the statistical evidence produced against them, league tables evidently represent a widely recognised and accepted ranking in the system of higher education. The tables also dispense with any false egalitarian beliefs in the equality of academic degrees and help employers recognise the differences between institutions. League tables and accreditation commissions are equally important and have a complementary role. The commissions have power and authority over whether an HEI can participate in the higher education market, whereas league tables establish a hierarchy among HEIs by ranking them according to objective criteria.

A shortage of academic staff is the third problem that both the Czech Republic and Poland face and their governments need to address. The rapid growth in the number of students has necessitated the employment of more professors, doctors and junior academics in order to retain the same quality of teaching. The number of students per academic teacher has risen to a very high level, which must have a negative impact on the quality of teaching and research. This problem is partly illustrated in Table 3. Earlier it affected mostly Poland, but in recent years the problem must also be faced in the Czech Republic. In both countries the average number of students per academic teacher has reached a dangerous level and further growth seems likely into the future. Unfortunately, owing to budget restrictions there is little hope that this situation is going to change in the near future. In addition, it takes at least a few years to educate junior academics with doctoral degrees, not to mention professors. 
Therefore there is another important dimension to the problem of a shortage of academics. The almost four hundred higher education institutions (especially in the private sector) require a large number of academic staff, which is simply unavailable. The high demand for education (and the money to be made out of this) makes the private institutions try to employ staff from the public universities, which are not willing to share their staff with the competitors. This has caused an enormous conflict between the private and public sector. Despite protests from the latter, most academics teach overtime in private schools and some are employed by several institutions at once. This pattern has become widespread, particularly among academics who have given up research and devote themselves solely to teaching. On the other hand, academics' salaries are humiliatingly low in relation to their qualifications and social status, and thus the opportunity to hold an additional job in the private sector is a sweet temptation that few academics can resist. The forthcoming act on higher education will likely reduce these problems by establishing a limit for the number of positions (probably two) an academic can hold.

Ironically, despite the different approaches Poland and the Czech Republic have taken to the reform of higher education, both countries face very similar problems and differences are mainly related to scale or scope. Neither the liberal approach (Poland) nor the conservative one (Czech Republic) succeeded in preventing a decline in the quality of teaching, an asymmetry of information, and a shortage of academic staff. However, in Poland all these issues have already become extremely damaging to higher education, despite desperate measures taken by the government. To be fair, it must be said that mass higher education (despite all the advantages) has caused massive problems. The Czech government can still have one without the other, but it must learn from the Polish experience and take action to prevent damaging side effects.

\section{(In)equalities in higher education}

The liberalisation of higher education was intended to create educational opportunities and to open new tertiary education institutions to those who want to study. In 1989/90 the indicator of scholarisation brutto among 19-24 year-olds was as low as $12.1 \%$ in Poland, and in 1994/95 25.4\%, but in the academic year 2001/02 it had reached a level of $45.2 \%$ in the same age group [Wasielewski 2003; Education... 1996, 2003]. This unquestionable progress appears to be a singular Polish phenomenon, as is evident from a comparison with figures for the Czech Republic: in 1994/95 net education enrolment was $22.4 \%$ and was almost unchanged in 2001/2002 at 23.1\% [Education... 1996, 2003]. As mentioned above, there are at least two types of study in Poland and the Czech Republic, and they correspond, on the whole, to two major categories - paid and unpaid. In Poland there are approximately $1700000 \mathrm{stu}-$ dents, of which more that 1200000 are required to pay for their education because they have either chosen to enrol in a private school or attend part-time or evening courses. Only 400000 students enjoy full-time status and can benefit from the 'luxury' of free education. 
In the Czech Republic, the figures are reversed: the number of students at private $\mathrm{HE}$ schools was 7891 in 2002/03, at public schools 235874. In other words the commercial form of study plays only a complementary role. Their existence does not make any significant contribution to widening access to higher education. In this respect higher education in Poland and the Czech Republic seem to have little in common. Enrolment in Czech higher education remains under state control (funding), and therefore since 1989 the indicator of scholarisation brutto has barely changed. According to Peter Scott [1995: 11] the most important and only permanent features of mass higher education systems are that they seem to be endlessly open and radically reflexive. In this perspective, Czech higher education remains an elite activity in the hands of the government. Unless the government significantly increases the higher education budget, there is little hope that the level of participation of students from socially and economically disadvantaged backgrounds will increase in the near future. This policy appears to be the opposite of Polish policy, where a significant increase in student numbers (from 400000 to 1800000 students) may indicate that the doors of higher education are opening wide to people from disadvantaged backgrounds. However, in practice these changes have only made the system slightly more fair, leaving much to be desired in terms of achieving equal opportunities. Despite the liberal policy and the widening access to academia there are still 'wicked issues' and unsolved problems concerning equal opportunities in higher education. This is illustrated by the strong connection between social position, specifically the father's education, and the type of studies to which students successfully obtain admission [Domański 1994]. The differentiation line is between free and paid higher education, separating the 'privileged' from the 'unprivileged'. Those from the first group are able to choose whatever they like to study (the school and type of studies), whereas the latter can only choose what is left.

There are at least two stages in the process whereby the higher education system reproduces social inequalities - social background and the father's education. A person is twice as likely to study in a free, public HEI if he or she is from an urban background than if he or she is from a rural area. This division is even sharper and more distinct when we take into consideration that geographic background has even greater impact on the possibility of a student's enrolment in well-established academic centres (which are generally well respected) - such as, in the case of Poland, Warsaw, Krakow or Torun - rather than in new ones (which tend to be less well respected) - such as Szczecin, Zielona Góra, or Częstochowa. The mythological nature of 'free education' and equal opportunities has been revealed in research by Ewa Świerzbowska-Kowalik [2000: 12] showing the strong impact of geographic background on students' enrolment. This means that the students who get the best education are mainly those who come from an urban background, where they have wider access to extra courses providing specific preparation for entrance examinations, well-equipped libraries, cultural events, and internet access. These circumstances may even sharpen existing inequalities instead of reducing them.

In the Czech Republic, this problem was not as serious. The increase in the inequalities in access to higher education that occurred after 1989 was caused by the 
substantial decrease in the odds of children from manual workers' families entering higher education. The odds ratio between unskilled and semi-skilled workers on the one hand and professionals on the other dropped from 0.37 to 0.26 . The socio-economic dimension of inequalities is therefore a crucial one [Matějů, Řeháková and Simonová 2003].

A similar issue worth considering is the impact of the level of the father's education on his child's chances of pursuing higher academic study. There seems to be no doubt that there is a strong, visible link between the father's education and the educational path of his children. In Poland, children whose fathers have higher education have twice the chance of enrolling in full-time higher education as those whose fathers have only secondary education in Poland. The impact is even stronger when those whose fathers have vocational education (four times less likely to attend full-time studies) and primary education (almost nine times less likely) are taken into account. This basically means that access to higher education, in particular to full-time study, which entails a considerably higher quality of teaching (e.g. more hours and smaller groups) and no tuition fees, depends heavily on not only geographic background, but also the father's education. According to Małgorzata Dziubińska-Michalewicz [2002: 36-37] and Witold Rakowski [2000], this division becomes much sharper in relation to popular subjects, such as law, management or sociology. From this perspective, equal opportunity is nothing but wishful thinking.

In the Czech case, the effect of the father's education remained unchanged in the period after 1989. However, this does not mean that access to higher education is equal among children whose fathers have different education levels. The odds ratio of children whose fathers had attained a tertiary education and those whose fathers had attained no more than lower secondary education (an apprenticeship) was constant in the years between 1948 and 1999: the odds of children of more educated fathers are 4.65 times higher. The relationship between children whose fathers had secondary and whose fathers had tertiary education was also constant but less (the odds are 2.16 times lower for children of less educated fathers) [Matějů, Řeháková and Simonová 2003].

\section{Conclusion}

Poland and the Czech Republic were both communist countries and had a highly bureaucratic system of higher education with a totalitarian nature. Despite this shared historical background, Poland and the Czech Republic chose different approaches to the reform of their systems of higher education.

In the case of Poland, the government's reforms were clearly designed to extend the opportunities for higher education. The reforms were very successful because they created a legal basis for establishing new private and public higher education institutions in order to extend the opportunities for a higher education. The number of students has increased dramatically in the past ten to twelve years, and 
the Poles enjoy a variety of options in terms of schools, subjects or alterative means of studying. Furthermore, the privatisation of Polish higher education was itself an interesting and successful process. Unlike other branches of the Polish economy, the rapid growth of private institutions in higher education was not a result of foreign investment, nor were they built from the state's ruined universities. This smooth progress was very unusual for private sector institutions, rendering the privatisation of higher education a unique phenomenon in the Polish economy. However, there was also a dark side to the reforms, as a number of higher education institutions evaded the state's control and the quality of teaching and research seriously declined. To make matters worse, a dispute between the public universities and private sector institutions has emerged over staff employment. Finally, the issue of equal opportunities leaves much to be desired in terms of providing equal access for students from different geographic and social background.

In the Czech Republic, the government has retained strong political control over higher education, making system less flexible and responsive to public demand. The system is bureaucratic and controlled from the top down, but unlike in Poland it is much easier to evaluate the quality of teaching and research provided by HEIs. In addition, with regard to the development of private higher education institutions, the process of liberalising higher education appears to have begun in the Czech Republic in 2000/2001 - ten years later than in Poland. The number of private $\mathrm{HE}$ institutions is currently increasing rapidly, but the market mechanism and real competition are still limited. This means that the real boom in education is probably yet to come, and the Czech government still has an opportunity to confront it adequately. However, in order to do so, it must learn from the Polish experience how to avoid the side effects of the transformation from elite to mass higher education.

NATALIE SimONOVÁ is a researcher at the Institute of Sociology where she works in the Department of the Sociology of Education and Stratification. Her research focuses on developments in educational inequality and educational mobility in the former Czechoslovakia and in the post-revolution Czech Republic. At present she is a doctoral student at the Faculty of Philosophy and Arts, Charles University in Prague, and she teaches at the Faculty of Social Sciences of Charles University.

DominiK ANTONOWICZ is an academic at the Institute of Sociology, Nicolaus Copernicus University in Torun, Poland. His major research field is in the higher education policy and university management. His doctoral thesis was written on the topic 'Plus ratio quam vis. The models of governmental policy toward universities'. He has recently published the book The University of the Future at the Institute of Public Affairs (Warsaw). 


\section{References}

Adamski, W. and I. Bialecki 1981. 'Selection at School and Access to Higher Education in Poland.' European Journal of Education 1: 209-223.

Beneš, Josef, Jeroen Huisman and Helena Šebková. 2003. 'Czech Republic.' Pp. 41-59 in Real-time Systems. Reflections on Higher Education in the Czech Republic, Hungary, Poland and Slovakia, edited by Jon File, Leo Goedegebuurenia. Brno-Twente: CHEPS.

Bowden, Rachel. 2000. 'Fantasy Higher Education: University and College League Tables.' Quality Higher Education 6 (1): 41-60.

Boguszak, M., P. Matějů and J. Peschar. 1990. 'Family Effect on Educational Attainment in Czechoslovakia, the Netherlands and Hungary.' Pp. 211-262 in Social Reproduction in Eastern and Western Europe: Comparative Analyses on Czechoslovakia, Hungary, the Netherlands and Poland, edited by J. Peschar. Nijmegen: Institute for Applied Social Sciences. Prague: Institute of Sociology, Czechoslovak Academy of Sciences.

Čerych, L. 2002. 'Higher Education Reform in the Czech Republic: A Personal Testimony Regarding the Impact of Foreign Advisers.' Higher Education in Europe 1-2: 111-121.

Danecki, Jan. 1997. 'Ubóstwo jako kwestia społeczna we współczesnej Polsce.' (Poverty as a Social Issue in Poland) Pp. 331-342 in Polska bieda II. Kryteria. Oceny. Przeciwdziatanie (The Polish Poverty II. Criteria, Evaluation, Prevention), edited by Stanisława Golinowska. Warszawa: IPiSS.

Domański Henryk. 1994. Społeczeństwo klasy średniej. (The Middle Class Society) Wydawnictwo IFiS PAN.

Domański, Henryk. 2000. 'Pochodzenie społeczne a poziom wykształcenia.' (The Social Origin and the Level of Education) Pp. 36-59 in Hierarchie i bariery spoteczne w latach dziewięćdziesiatych. (Hierarchies and Social Barriers in the 1990), edited by Henryk Domański. Warsaw: Wydawnictwo IFiS PAN.

Dziubińska-Michalewicz, Małgorzata. 2002. 'Nierówności społeczne: zróżnicowanie płac, dostęp do edukacji, uczestnictwo w kulturze.' (Social Inequalities: Differences in Salaries, Access to Education, Participation in Culture) Pp. 18-43 in Dawne i nowe problemy spoteczne (The Old and the New Social Problems), edited by Andrzej Kojder. Warszawa: Biuro Studiów i Ekspertyz Kancelarii Sejmu.

Education at a Glance 1996. Paris: OECD.

Education at a Glance 2003. Paris: OECD.

Goldthorpe, J. 1996. 'Class Analysis and the Reorientation of Class Theory: The Case of Persisting Differential in Educational Attainment.' British Journal of Sociology 47: 481-505.

GUS (The National Statistics Office). 2001. 'Szkoły wyższe i ich finanse w 2000 r.' (Higher Education Institutions and Their Finance in the Year 2000) Informacje i Opracowanie Statystyczne GUS, Warsaw.

Haller, M., B. W. Mach. 1984. 'Structural Changes and Mobility in a Capitalist and a Socialist Society: Comparison of Men in Austria and Poland.' Pp. 43-107 International Comparative Research: Social Structure and Public Institutions in Eastern and Western Europe, edited by M. Niessen, J. Peschar and C. Kourilsky. Oxford: Pergamon Press.

Hanley, Eric 2001. 'Centrally Administered Mobility Reconsidered: The Political Dimension of Educational Stratification in State-Socialist Czechoslovakia.' Sociology of Education 74: 25-43.

Heyns, B. and I. Bialecki. 1993. 'Educational Inequalities in Postwar Poland.' Pp. 303-335 in Persistent Inequality. Changing Educational Attainment in Thirteen Countries, edited by Y. Shavit, H. P. Blossfeld. Boulder - San Francisco - Oxford: Westview Press.

Historická statistická ročenka ČSSR (Historical Yearbook in the Czech and Slovak Socialist Republic). 1985. Prague: SNTL. 
Jabłecka, Julita. 1994. 'Reflections on the Polish Higher Education.' Pp. 11-25 in Changes in Higher Education, edited by Julita Jabłecka, Ireneusz Białecki, Małgorzata DąborwaSzefler. Warsaw: Centre for Science Policy and Higher Education.

Kay, John and Jane Vickers. 1988. 'Regulatory Reform in Britain' Pp. 286-343 Economic Policy 7: 286-343.

Kreidl, M. 2001. 'The Role of Political, Social and Cultural Capital in Secondary School Selection in Socialist Czechoslovakia, 1948-1989.' Sociological Papers. Prague: Institute of Sociology, Czechoslovak Academy of Sciences.

Mach, B. W. and J. L. Peschar. 1990. 'On the Changing Role of Education in Social Reproduction in Different Socio-Political Systems. A Comparative Analysis between Poland and the Netherlands.' Pp. 125-148 in Social Reproduction in Eastern and Western Europe, edited by J.L. Peschar. Nijmegen: OOMO.

Matějů, P. 1986. 'Demokratizace vzdělání a reprodukce vzdělanostní struktury v ČSSR ve světle mobilitních dat.' (The Democratisation of Education and the Reproduction of Educational Structures in CSSR) Sociologický časopis 2: 131-152.

Matějů, P. 1990. 'Family Effect on Educational Attainment in Czechoslovakia, the Netherlands and Hungary.' Pp. 187-210 in Social Reproduction in Eastern and Western Europe, edited by J.L. Peschar. Nijmegen: OOMO.

Matějů, Petr. 1993. "Who Won and Who Lost in a Socialist Redistribution in Czechoslovakia?" Pp. 251-271 in Persistent Inequality. Changing Educational Attainment in Thirteen Countries, edited by Y. Shavit and H. P. Blossfeld. Boulder - San Francisco Oxford: Westview Press.

Matějů, P. and M. Kreidl 2001. 'Rebuilding Status Consistency in a Post-Communist Society. The Czech Republic, 1991-97.' Innovation 1: 17-34.

Matějů, P., B. Řeháková and N. Simonová. 2003. ‘Transition to University under Communism and after Its Demise. The Role of Socio-economic Background in the Transition between Secondary and Tertiary Education in the Czech Republic 1948-1998.' Czech Sociological Review 3: 301-324.

McMullen, M.S. and J. Prucha. 2000. 'The Czech Republic. A Country in Transition ...Again.' Pp. 47-75 in The Emerging Markets and Higher Education. Development and Sustainability, edited by M.S. McMullen, J. E. Mauch and B. Donnorummo. New York: RoutledgeFalmer.

Meyer, J. W., N. B. Tuma and K. Zagórski. 1979. 'Education and Occupational Mobility: A Comparison of Polish and American Men.' American Journal of Sociology 84: 978-986.

Nieuwbeerta, P. and S. Rijken. 1996. 'Educational Expansion and Educational Reproduction in Eastern Europe, 1940-1979.' Czech Sociological Review 2: 187-210.

Misztal, Bronisław. 2000. Prywatyzacja szkolnictwa wyższego w Polsce. (The Privatisation of the Higher Education in Poland) Warszawa: Universitas.

Peschar, J. L., R. Popping and B. W. Mach. 1986. 'Educational Mobility in Poland and the Netherlands.' Netherlands Journal of Education 1: 119-139.

Pohoski, M., S. Pontinen and K. Zagórski. 1978. 'Social Mobility and Socio-economic Achievement.' Pp. 147-182 in Social Structure and Change. Finland and Poland: Comparative Perspective, edited by E. Allardt, W. Wesolowski. Warszawa: Polish Scientific Publishers.

Rakowski, Witold. 2000. Sytuacja środowiska studenckiego. Pochodzenie spoteczne i status materialny. (The Situation of Students. The Social Origin and Material Status) Warszawa: Biuro Studiów i Ekspertyz Kancelarii Sejmu.

Rutkowski, Jan. 1996. 'Wykształcenie a perspektywy na rynku pracy.' (Education and the Prospects on the Labour Market) . Nauka i Szkolnictwo Wyższe 7: 81-92.

Simonová, Natalie. 2003. 'The Evolution of Educational Inequalities in the Czech Republic after 1989.' British Journal of Sociology of Education 4: 469-483. 
Sorensen, Karen M. 1993. ‘Presja zmiany i możliwości ich wprowadzania w systemie zarządzania w szkołach wyższych.' (The Pressure of Change and the Possibilities of Their Implementation in Higher Education Institutions) Nauka i Szkolnictwo Wyższe 2: 35-45.

Scott, Peter 1995. The Meanings of Mass Higher Education. Open University Press: Buckingham.

Świerzbowska-Kowalik, Ewa. 2000. 'Wykształcenie środowisk rodzinnych i miejsce zamieszkania jako wyznaczniki szans na podjęcie studiów.' (The Family's Education as an Indicator of Higher Education Opportunities) Nauka i Szkolnictwa Wyższe 2 (16): 108-135.

Tomusk, V. 2000. 'Reproduction of the State Nobility in Eastern Europe: Past Patterns and New Practices.' British Journal of Sociology of Education 2: 269-282.

Večerník, J. 2001. Earnings Disparities in the Czech Republic: Evidence of the Past Decade and Cross-National Comparison. William Davidson Institute, University of Michigan Business School, Working Paper 373, May 2001.

Wasielewski, Krzysztof. 2001. 'Private Universities in Poland.' Kultura i Edukacja 2: 22-35.

Wasielewski, Krzysztof. 2003. 'Przmiany w kształceniu na studiach wyższych w Polsce. Przypadek Socjologii.' (The Changes in Teaching in Higher Education. The case of Sociology). AUNC. Socjologia Wychowania XV: 59-80.

Williams, Gareth. 1997. 'The Market Rout to Mass Higher Education: British Experience 1979-1996.' Higher Education Policy 10 (3-4): 275-289.

Wong, Raymond Sin-Kwok. 1998. 'Multidimensional Influences of Family Environment in Education. The Case of Socialist Czechoslovakia.' Sociology of Education 71: 1-22. 